\title{
МАТЬ И ДИТЯ В РАННЕЙ СОВЕТСКОЙ ПОЛИТИКЕ: СЛУЧАЙ ДАГЕСТАНА
}

В статье анализируется советская социальная политика 1920-1930-х гг. в области охраны материнства и детства в Дагестане. На основе архивных материалов, опубликованных документов, литературы и периодики раскрываются ее основные тенденции. Анализ позволил выстроить целостную картину преобразований в области медицинской помощи горянкам, их эмансипации, включения в общественную жизнь. Документальные материалы отражают сложности проникновения советских преобразований в дагестанские селения. Советское здравоохранение столкнулось с традиционными медицинскими практиками, которые формировались на протяжении длительного времени. Население пользовалось услугами местных повитух, которые не имели какого бы то ни было профессионального образования, что связано с отсутствием в Дагестане специализированных учебных заведений. Однако уже в середине 1920-х гг. открыта акушерскофельдшерская школа, которая занялась подготовкой квалифицированных медицинских работников. Постепенно с ростом числа медицинских работников количество родов, которые принимались в стационарах, начинает расти, увеличивается и число коек в лечебных заведениях, открываются колхозные родильные дома. Создаются комиссии по охране материнства и детства, в чьи обязанности входила организация чтения лекций по санитарному просвещению, методическая помощь медицинским работникам. Как показывают статистические данные, до введения запрета на производство абортов их число в Дагестане было значительным. Запрет абортов привел к росту рождаемости и открытию родильного дома в Махачкале. Создание Дагестанского медицинского института в 1932 г. и в его рамках кафедр детских болезней и акушерства и гинекологии положительно сказалось на оказании квалифицированной медицинской помощи матерям и детям. Включение горянок в общественную

Сергей Борисович Манышев - соискатель, Институт российской истории РАН, Москва, Россия. Электронная почта: msergey1990@gmail.com 
жизнь повлекло за собой открытие большого числа как стационарных, так и сезонных дошкольных детских учреждений. В статье показано, что несмотря на голод, нежелание местных жителей прибегать к квалифицированной медицинской помощи, а также иные трудности, связанные с проведением советской социальной политики, в 1920-1930-е гг. в Дагестане наблюдался естественный прирост населения.

Ключевые слова: Дагестан, 1920-1930 гг., охрана материнства, история здравоохранения, социальная политика, родовспоможение

DOI: $10.17323 / 727-0634-2019-17-1-75-88$

Особенностью дагестанского общества в первой трети XX в. была архаичность семейных практик, что во многом связано со сложившимися социальными условиями. Это создало существенные препятствия для советской политики медицинской модернизации в регионе. В начале XX в. в Дагестане наблюдался дефицит квалифицированных медицинских работников: в 1914 г. из положенных по штату 18 врачей в округах работало лишь пять, а из необходимых 44 фельдшеров - 20 (Аликишиев 1958: 80-81). Население предпочитало обращаться к знахарям и народным лекарям, причем такое положение сохранялось и в послереволюционное время. В 1927 г. доктор С. Имамалиев писал:

Казалось бы, давно должен быть положен конец знахарству в Дагестане. Между тем, ежедневно народный комиссариат здравоохранения осаждают знахари из различных округов с просьбой разрешить им официально заниматься лечением больных. Очень часто знахари запасаются хорошими отзывами от сельсоветов и исполкомов «об опытности и добросовестности» в своей знахарской профессии <... Стаж у всех знахарей солидный - от 10 до 40 лет. (Имамалиев 1927:2).

Фактором неприятия советской политики в области здравоохранения стало почти полное отсутствие национальных медицинских кадров в первые десятилетия советской власти. Врачи из других регионов, работая в аулах без знания языков и местной специфики, оказывались беспомощными, а их профессиональные знания - невостребованными. Медицинские работники также сталкивались с тем, что они не могли обследовать и лечить женщин в силу религиозных ограничений (Маркин 1927: 10). Эти факторы выделяют Дагестан из общего контекста советских социальных преобразований.

Вопросы, связанные с оказанием медицинской помощи беременным, как на Северном Кавказе, так и в Дагестане, ранее становились предметом изучения. Уже в начале 1930-х гг., после комплексного исследования, проведенного в Дагестане сотрудниками Института социальной гигиены, появились работы, анализирующие состояние рождаемости и детской смертности (М.М. 1930; Епифанова 1930). В дальнейшем историография данного вопроса концентрировалась исключительно на успехах советской 
власти, не затрагивая тех проблем, с которыми сталкивались врачи и пациенты (Пыпа 1960; Абдулжанова 1978). Опубликован ряд работ, освещающих охрану материнства и детства на Северном Кавказе в XIX-XX вв. (Яхъяева, Батаев 2012; Яхъяева 2014). Путем анализа архивных материалов я попытался доказать, что, несмотря на все особенности региона, советская социальная политика в Дагестане в 1920-1930-е гг. была результативной и оказала решающее влияние на естественный прирост населения.

\section{Традиционные практики}

Многодетность дагестанской семьи была связана с целым рядом факторов. В первую очередь, наличие большого количества детей давало бесплатную рабочую силу для обработки земли и прочих домашних работ. Во-вторых, отсутствовало такое понятие, как «планирование семьи», хотя горцы знали о средствах контрацепции (см.: Мусаева 2013:373-374). Как можно судить по сохранившимся нормам обычного права, народам Дагестана не были чужды аборты, проводившиеся местными знахарками (Бобровников 2009: 127). С другой стороны, этнограф и правовед Башир Далгат отмечал, что у даргинцев «плодоизгнание считается величайшим преступлением против религии» (цит. по: Омаров 1968: 118).

В первой половине XX в. роды, как правило, проходили в доме мужа. Мужчинам запрещалось находится в одном помещении с роженицей, ее окружали исключительно женщины, как это было и в XIX в. Роды принимали повитухи (Djandar 2008:258). Они образовывали своеобразные династии и передавали свои знания исключительно в рамках одной семьи. В кумыкском селении Муслимаул в середине XIX в. практиковала повитуха по имени Энечи Халимат, которая получила необходимые навыки от своей матери и передала их своей дочери Абай, продолжившей принимать роды у сельчанок в 1920-1930е гг. (ПМА 2013). По всей видимости, в рассматриваемый период, как и прежде, в каждом дагестанском селе две-три женщины занимались родовспоможением (Монин 1905: 105; Айвазова 1899:204). Квалифицированные акушерки, окончившие медицинские техникумы, не могли составить им конкуренции. Как отмечала в 1938 г. акушерка Мария Кизилева, работавшая в селении Великент (1938:3), женщины не обращались к ней за специализированной помощью, а лишь приходили за советом, предпочитая рожать у местных повитух.

Советской властью деятельность знахарок и «бабок» всячески высмеивалась и порицалась. На страницах «Дагестанской правды» отмечалось, что открытие родильного отделения при районной больнице - «первый и большой шаг к тому, чтобы вырвать матерей-горянок из цепких рук бабок» (Дагестанская правда 1936:2). Кроме того, в рамках трехдневника охраны материнства и младенчества, организуемого повсеместно, рекомендовалось устраивать «показательные инсценировки», среди которых был «Суд над бабкой» (Завалищенко 1973: 87). 


\section{Стратегии советской социальной политики}

Несмотря на то, что своими декретами советская власть обеспечивала полное равноправие мужчин и женщин, на деле все оказывалось намного сложнее. С целью экономической и социальной эмансипации женщин в 1920-е гг. повсеместно создавались отделы по работе среди женщин (женотделы). Однако привлечь в них женщин в Дагестане оказалось непростой задачей, так как большинство горянок просто не понимало того, чем будут заниматься такие организации (Дзагурова, Михайлова 1979: 105). Работа женотделов в горах проводилась через делегаток, которые прикреплялись к сельсоветам и таким образом осуществляли пропаганду новых знаний. К примеру, в Гунибском округе врач по фамилии Красикова пыталась привить горянкам знания из области охраны материнства и детства путем чтения еженедельных лекций членам женсоветов (ЦГА РД. Ф. П-1. Оп. 1. Д. 707. Л. 34).

Перед новой властью в Дагестане стоял целый ряд проблем и непосредственно в области здравоохранения и социальной политики. В конце ноября 1921 г. народный комиссар здравоохранения ДАССР Р.Н. Шихсаидов говорил: «Война, революция и постоянные партизанские выступления в горах довели медицинскую помощь населению округов до минимума, близко подходящего к нулю» (цит. по: Исрапилов 1960:350). В это время в Дагестане на более чем миллионное население приходилось десять врачей, 37 лекарских помощников, из которых только семь имели специальное образование. Распределены они были в 12 сельских и двух городских больницах, а также в пяти фельдшерских пунктах, разбросанных по территории республики и не представлявших собой единой сети (Саградов 1920:2).

Еще в 1921 г. в составе Наркомздрава создан отдел охраны материнства и детства, но спустя четыре года его руководитель констатировал, что «работа матмлада [отдел охраны материнства и младенчества] находится до сих пор еще в зачаточном состоянии». Ввиду нехватки средств, невозможно осуществить все те проекты, которые задумывались руководством, но «были предприняты первые шаги в вопросе проникновения рациональной акушерской помощи в гущу горских женщин» (ЦГА РД. Ф. Р-37. Оп. 21. Д. 137. Л. 3). В середине 1920-х гг. начали создаваться постоянные комиссии по охране материнства и младенчества. В их состав включались представители власти, медицинские работники, организаторы по работе с женщинами, а также делегатки от горянок. Такие комиссии должны были собираться не реже одного раза в месяц. Перед ними были поставлены задачи увеличения числа акушерок на местах и организация родильных отделений при больницах и летних яслей, а также проведения разъяснительной работы (ЦГА РД. Ф. Р-23. Оп. 6. Д. 16. Л. 1). Был определен перечень тем для делегатских собраний, на которые необходимо было прочесть лекции. При этом тематика для городских и сельских собраний 
несколько отличалась, так как сельским жителям необходимо было разъяснять нововведения в области здравоохранения (ЦГА РД. Ф. Р-23. Оп. 6. Д. 16. Л. 2). Лекции эти читались исправно, о чем свидетельствует письмо заведующего райздравотдела Дербентского района, в котором он отмечает, что к сентябрю 1925 г. их программа была исчерпана (ЦГА РД. Ф. Р-23. Оп. 6. Д. 16. Л. 4).

Из-за катастрофической нехватки квалифицированных кадров в начале 1920-х гг. в Дагестане остро встал вопрос о подготовке медиков. Однако в это время так и не удалось открыть фельдшерскую школу (Нагиева 2015: 65). К идее организации акушерского техникума вернулись только в 1926 г. Низкий уровень подготовки будущих студентов заставил организовать при техникуме подготовительные курсы для девушек-горянок, которые хотели стать акушерками (Коган, Юсупова 1980: 197-198). К началу 1925 г. в Дагестане было 30 акушерок (ЦГА РД. Ф. Р-23. Оп. 7. Д. 1. Л. 5), но с открытием фельдшерско-акушерской школы их число стало расти от года к году: с 1925 по 1940 гг. школа выпустила 258 акушерок, которые оказывали квалифицированную помощь по всему Дагестану (Аликишиев 1958: 133).

Оценивая динамику рождаемости в регионе на фоне этих усилий органов власти, следует учитывать и политику советского государства в отношении абортов. В первой половине 1920-х гг. она была направлена на создание необходимых медицинских условий для их проведения. Брачный кодекс 1926 г. юридически закрепил право женщины на искусственное прерывание беременности (Hoffmann 2011: 137). Однако уже с начала 1930-х гг. аборты начали достаточно жестко регулироваться государством: за их производство введена высокая плата (от 25 до 300 рублей), которая зависела от уровня обеспеченности женщины (Вишневский 2006: 199-215). В 1936 г. принято постановление ЦИК и СНК СССР, которое регламентировало производство абортов в стране. Отныне они могли проводиться исключительно по медицинским показаниям, при этом для врачей устанавливался тюремный срок от одного года до двух лет, а для женщин - общественное порицание и штраф до 300 рублей при повторном нарушении закона (Завалищенко 1973:247-248).

Только в 1934 г., пока аборты были узаконены, по официальной статистике в городах Дагестана их было сделано 4005, в сельской местности 421. Принято 2429 родов в городах и 1540 в сельской местности (ЦГА РД. Ф. Р-23. Оп. 26. Д. 9. Л. 9 об.). Стоит также отметить, что на 143 койки родильных отделений в ДАССР приходилось 29 коек абортных отделений (ЦГА РД. Ф. Р-23. Оп. 26. Д. 9. Л. 1 об.). Изменение в «абортной» политике вызвало краткий «бэби-бум». Это привело к необходимости строительства специализированного родильного дома в Махачкале вместо отделения в городской больнице. Если в 1933 г. в городе принято 640 родов, то только за два месяца 1937 г. зарегистрировано 440 родов (Алиев 1937:3). Как видно (табл. 1), число родов в 1937 г. в целом по ДАССР выросло на 7356 (22,58\%). 
Однако уже в следующем году их число приходит приблизительно к тому же, которое было до запрета абортов, что было связано с расцветом нелегальных способов прерывания беременности. Одновременно с подъемом рождаемости в городах имел место скачок младенческой смертности. Вероятно, он был вызван неблагоприятной санитарной обстановкой. Как отмечалось в секретной записке начальника отдела демографии ЦУХНУ, $46 \%$ смертей в младенческом возрасте в Махачкале в 1937 г. составляли смерти от желудочно-кишечных заболеваний (РГАЭ. Ф. 1562. Оп. 329. Д. 256. Л. 129). Стоит при этом заметить, что младенческая смертность к 1939 г. в ДАССР была несколько ниже, чем в РСФСР, где она составляла 18,8 \% к числу родившихся, и по СССР в целом (16,75\%) (РГАЭ. Ф. 4372. Оп. 92. Д. 284. Л. 14).

Таблица 1

Рождаемость и младенческая смертность по ДАССР

\begin{tabular}{|c|c|c|c|c|c|c|c|c|c|}
\hline \multirow[b]{2}{*}{8} & \multicolumn{3}{|c|}{ Городское население } & \multicolumn{3}{|c|}{ Сельское население } & \multicolumn{3}{|c|}{ Итого по ДАССР } \\
\hline & 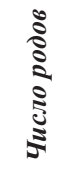 & 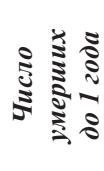 & $\frac{0}{3}$ & 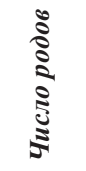 & 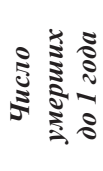 & 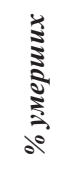 & $\begin{array}{l}0 \\
\vdots \\
\vdots \\
\vdots \\
5 \\
5 \\
5\end{array}$ & 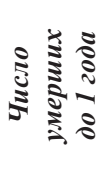 & 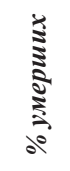 \\
\hline 1935 & 5608 & 831 & 14,81 & 18584 & 2128 & 11,45 & 24192 & 2959 & 12,23 \\
\hline 1936 & 6128 & 1040 & 16,97 & 26440 & 2578 & 9,75 & 32568 & 3618 & 11,10 \\
\hline 1937 & 8316 & 1951 & 23,46 & 31608 & 3665 & 11,59 & 39924 & 5184 & 12,98 \\
\hline 1938 & 7052 & 1199 & 17,00 & 25483 & 3019 & 11,84 & 32535 & 4218 & 12,96 \\
\hline 1939 & 7225 & 1172 & 16,22 & 27311 & 2892 & 10,58 & 34536 & 4064 & 11,76 \\
\hline 1940 & 7234 & 1343 & 18,56 & 27381 & 3881 & 14,17 & 34600 & 5224 & 15,09 \\
\hline
\end{tabular}

* Источники: ЦГА РД. Ф. Р-22. Оп. 23. Д. 9. Л. 5-7 об. Д. 11. Л. 16-18 об. Д. 12. Л. 20, 29, 37. Д. 13. Л. 4-6 об. Д. 14. Л. 4-6 об. Д. 15. Л. 2-4об.

Одновременно с кратковременным «бэби-бумом» были предприняты попытки увеличить число родов в стационарах. Постановлением от 25 июня 1937 г. СНК ДАССР рекомендовал развернуть дополнительные койки в родильных домах. Всего на эти цели выделялось 192 тыс. руб. и предполагалось развернуть 45 родильных коек: 30 в городе Кизляре, десять в Буйнакске и пять в Дербенте (ЦГА РД. Ф. Р-168. Оп. 17. Д. 64. Л. 82-83). К 1940 г. в Дагестане функционировали всего десять родильных домов на 116 коек, работало 28 врачей акушеров-гинекологов, 255 акушерок и 61 фельдшерица-акушерка (Абдулжанова 1978: 25), наблюдалась недогруженность коек, которая была связана с недостаточным оборудованием, нехваткой медицинского инвентаря (Алиев 1937:3). Простой коек объяснялся недоверием к профессиональным врачам и акушеркам (Маркин 1927:3). В 1927 г. 
на Северном Кавказе от общего числа родов в городах госпитализировалось $35 \%$ женщин, в сельской местности - 3,4\% (Яхъяева 2014: 17).

В середине 1930-х гг. советское правительство приняло решение улучшить организацию медицинской помощи беременным в сельской местности. С этой целью были созданы колхозные родильные дома, которые должны были оказывать стационарную помощь. По замыслу, они должны были создаваться по инициативе самих колхозников и финансироваться колхозами на $75 \%$, а еще на $25 \%$ датироваться государственным бюджетом. Райздравотделы обеспечивали колхозные роддома акушерами (Гиндоман 1939:26-27). СНК РСФСР своим постановлением разрешил Наркомздраву принять на средства госбюджета зарплату акушерок (Завалищенко 1973:244). К 15 августа 1936 г. в Дагестане было открыто 11 колхозных роддомов на 20 коек вместо планируемых 24 на 66 коек. Они были размещены в неприспособленных помещениях и не были оборудованы. Колхозы не обеспечивали роддома необходимыми продуктами питания. СНК ДАССР предложил Наркомздраву выявить акушерок, работавших не по специальности, для укомплектования ими этих учреждений (ЦГА РД. Ф. Р-23. Оп. 29. Д. 3. Л. 36).

В Махачкале была единственная на весь Дагестан детская амбулатория. Она была очень востребована, так как за 300 дней ее работы в 1924 г. число обращений составило 8672 (ЦГА РД. Ф. Р-23. Оп. 7. Д. 1. Л. 13). Она также располагалась в неприспособленном помещении: в квартире, состоящей из шести комнат, «где нет никакой возможности развернуть ту многосложную работу, которую должна проводить детская амбулатория столицы ДАССР» (Казаров 1938а:3).

Определенную роль в оказании медицинской помощи матери и ребенку в Дагестане со второй половины 1930-х гг. взяли на себя кафедры открытого в 1932 г. медицинского института. В первую очередь возглавляемая доцентом Петром Давыдовым кафедра детских болезней, которой было организовано общество врачей-педиатров, оказывавшее научно-практическую помощь специалистам. «Но, как ни странно,- писал один из старейших врачей Дагестана в «Дагестанской правде» в 1938 г.,-- врачи-педиатры не принимают участия в работе этого общества, держат себя обособленно, вследствие чего страдает и лечебное, и профилактическое дело детских лечучреждений» (Казаров 1938b: 3). Спустя год после этого выступления, в марте 1939 г. созвана межреспубликанская конференция по борьбе с детскими заболеваниями, в которой приняли участие педиатры и эпидемиологи из Дагестана, Чечено-Ингушетии, Кабардино-Балкарии и Северной Осетии. На ней было отмечено, что благодаря усилиям Давыдова в Махачкале удалось организовать круглосуточную помощь детям. Общество врачей-педиатров провело выезды в города Дагестана и поселки Избербаш, Двигательстрой и Дагестанские Огни, где оказало научно-методическую и практическую помощь работникам здравоохранения (Дагестанская правда 1939: 4). 
В 1925 г. в Дагестане функционировало три ясельных группы на 80 детей (ЦГА РД. Ф. Р-23. Оп. 7. Д. 1. Л. 16). Такое незначительно число было связано с отсутствием финансов на их содержание (ЦГА РД. Ф. Р-37. Оп. 21. Д. 140. Л. 13). Однако включение горянок в общественную жизнь, невозможность оставаться целый день с детьми вынуждали отдавать детей в дошкольные учреждения. Это встречало сопротивление со стороны патриархального населения Дагестана. Работники женотделов проводили разъяснительную работу, устраивали торжественные открытия сезонных яслей (Смирнова 1983: 136), и к началу 1930-х гг. их число превысило две сотни (Аликишиев 1958: 117).

\section{Итоги советской социальной политики}

Основные тенденции социальной политики рассматриваемого периода нашли свое отражение в демографическом развитии Дагестана. Период революции и Гражданской войны сказался на нем крайне негативно. Тогда население Дагестана сократилось на 10-15\% (Магомедов 1980: 42), а ряд авторов утверждает, что на 23\% или 167 тыс. человек (Ибрагимов 2013: 79). Однако на протяжении 1920-х гг. происходил рост населения: естественный прирост в сельской местности в 1924-1926 гг. оценивался в 2,03\%, а в городах - в 1,6\%. При этом среднегодовой естественный прирост, рассчитанный на материалах 20 лет, предшествующих Первой мировой войне, составлял 0,38 \% (Малыгин 1927: 114, 115). Согласно исследованию, проведенному сотрудниками Института социальной гигиены во второй половине 1920-х гг. на материалах дагестанских сел Цудахар и Мекеги, на период между 1921 и 1926 гг. приходится снижение младенческой и детской смертности (Епифанова 1930: 72). Достаточно высоким оставался показатель младенческой смертности в городах в 1926-1928 гг. Он колебался от 13,4 \% к числу родившихся в Кизляре до $24 \%$ в Буйнакске (М.M. 1930:99). В этническом аспекте наиболее высокий показатель детской смертности в возрасте до года в городах наблюдался у кумыков (составлял в среднем за три года 29,5\% к числу родившихся). Далее идут «татары» и «персы» по 24,3\% и $25 \%$, горцы - 20,5\%, русские - 20,1\%, армяне 13,7\%, прочее население городов - 8,7\% (М.M. 1930: 101).

С 1926 г. по 1937 г. естественный прирост населения в Дагестане составил 28,3 \% (Жиромская, Поляков 2007:38), несмотря на то, что в 1933 г. здесь наблюдалась высокая смертность, вызванная голодом (Андреев и др. 1993: 47). Похожие тенденции фиксировались в то время в целом ряде регионов СССР, выделенных начальником Центрального управления народохозяйственного учета И. А. Кравалем в особую группу национальных республик и областей, отличавшихся как высоким естественным приростом, так и большим притоком населения извне. Такая же ситуация отмечалась повсеместно в национальных автономиях Северного Кавказа: 
Карачаевской AO (46,1\%), Черкесской АО (20,3\%), Чечено-Ингушской АССР (27,7\%), Северо-Осетинской АССР (34,5 \%), Кабардино-Балкарской АССР (40,2\%). В целом рост населения СССР с 1926 по 1937 г. составил 10,2\% (Жиромская 2000: 347-351).

Советская политика в области охраны материнства и детства и ее воплощение в Дагестане носили неоднозначный и противоречивый характер. С одной стороны, из года в год увеличивалось число медицинских работников, росло количество амбулаторий и стационаров, что свидетельствует о понимании руководством страны важности этого направления социальной политики. С другой стороны, патриархальные пережитки, укоренившиеся в быту народов Дагестана, не всегда давали возможность проникать в жизнь горцев тем начинаниям, которые должны были улучшить качество их жизни. Тем не менее к середине 1930-х гг. наметилась тенденция ежегодного положительного естественного прироста населения. То есть в целом, несмотря на разницу стартовых условий, результаты социальной политики 1920-1930-х гг. в Дагестане соответствовали общесоветским тенденциям.

\section{Список сокращений}

РГАЭ - Российский государственный архив экономики. ЦГА РД - Центральный государственный архив Республики Дагестан.

\section{Описание полевых данных}

ПМА (2013) - Полевой материал автора. Экспедиция в Буйнакский район Республики Дагестан. Село Атланаул.

\section{Список источников}

Абдулжанова Ф.С. (1978) Охрана здоровья женщины-матери и ребенка. Махачкала: Дагкнигоиздат.

Айвазова С. (1899) Народное акушерство в Закатальском округе. (Из записок акушерки). Акушерка: Общедоступный медицинский журнал, (13-14): 203-210.

Алиев М. (1937) Махачкале нужен родильный дом. Дагестанская правда, (51): 3.

Аликишиев Р.Ш. (1958) Очерки по истории здравоохранения Дагестана. М.: Медгиз.

Андреев Е. М., Дарский Л.Е., Харькова Т. Л. (1993) Население Советского Союза. 1922-1991. М.: Наука.

Бобровников В.О. (ред.) (2009) Обычай и закон в письменных памятниках Дагестана Vначала ХХ в. T. II: В изарской и ранней советской России. М.: Марджани.

Вишневский А.Г. (ред.) (2006) Демографическая модернизация России, 1900-2000. М.: Новое издательство. 
Гиндоман Д. (ред.) (1939) Сборник положений и инструкиий по работе учреждений родовспоможения. М.: [б.и.].

Дагестанская правда (1936) Знахарское «акушерство», (137): 2.

Дагестанская правда (1939) Межреспубликанская конференция по борьбе с детскими заболеваниями, (70): 4 .

Дзагурова Ю.П., Михайлова Н.В. (ред.) (1979) Великий Октябрь и раскрепощение женщии Северного Кавказа и Закавказья. 1917-1936 г2. Сборник документов и материалов. М.: Мысль.

Епифанова А.Г. (1930) Плодовитость даргинской женщины и детская смертность. А.В. Мольков (ред.) Социально-гигиеническое исследование народностей Дагестана. Bыn. I: Даргинцыы. М.: Медгиз: 61-75.

Жиромская В.Б. (ред.) (2000) Население России в ХХ веке: Исторические очерки. Т. 1: 1900-1939. М.: РОССПЭН.

Жиромская В.Б., Поляков Ю.А. (ред.) (2007) Всесоюзная перепись населения 1937 года: Общие итоги: Сборник документов и материалов. М.: РОССПЭН.

Завалищенко Л.И. (ред.) (1973) Здравоохранение в годы восстановления и социиалистической реконструкции народного хозяйства СССР. 1925-1940. Сборник документов и материалов. М.: Медицина.

Ибрагимов М.-Р.А. (2013) Демографическая ситуация в Дагестане в годы Гражданской войны. Б.Б. Булатов (ред.) Северо-кавказский исторический дискурс Гражданской войны в России (1917-1922 г2.). Материалы международной научно-практической конференции, посвященной 200-летию вхождения Дагестана в состав России, 20 октября 2013 г. Вып.1. Махачкала: ДГУ: 74-80.

Имамалиев [С.] (1927) Знахарство в Дагестане. Красный Дагестан, (37): 2.

Исрапилов А.К.-М. (ред.) (1960) Револючионные комитеты Дагестана и их деятельность по упрочению Советской власти и организации сочиалистического строительства. (Март 1920 г.- декабрь 1921 г.). Махачкала: Дагестанское книжное издательство.

Казаров [С.] (1938а) Внимание детской амбулатории. Дагестанская правда, (22): 3 .

Казаров [С.] (1938b) Созвать конференцию врачей-педиатров. Дагестанская правда, (293): 3 .

Кизилева М. (1938) Рассказ сельской акушерки. Дагестанская правда, (300): 3.

Коган Г.Д., Юсупова С.И. (ред.) (1980) Культурное строительство в Дагестанской АССР. T. 1: 1918-1941. Сборник документов. Махачкала: Дагестанское книжное издательство.

M.M. (1930) Показатели ранней детской смертности в городах ДАССР в связи с показателями рождаемости и общей смертности. Плановое хозяйство Дагестана, (1-2): 97-102.

Магомедов А. Д. (1980) Движение населения Дагестана в годы Гражданской войны. Г.Ш. Каймаразов (ред.) Гражданская война на Северном Кавказе. (Закономерности 
и особенности): Региональная научная конференция. Тезисы докладов. Махачкала: ИИЯЛ ДФ АН СССР: 42-43.

Малыгин М. (1927) К вопросу о естественном движении населения ДССР. (Опыт исследования). Плановое хозяйство Дагестана, (7-8): 81-118.

Маркин А.И. (1927) Лечебное дело в автономных областях Северо-Кавказского края. Советская медицина на Северном Кавказе, (10): 3-10.

Монин Л.М. (1905) О нравах и обычаях среди мусульманского населения некоторых местностей Закавказья и Северного Кавказа по отношению к беременным, роженицам, родильницам и новорожденным. Медицинский сборник, издаваемый императорским Кавказским медииинским обществом. Т. 67. СПб.: Типография Т-ва М.О. Вольфа:99-114.

Мусаева М.К. (2013) Внутрисемейный контроль рождаемости: традиционная практика применения контрацепции у народов Дагестана. Ю. Ю. Карпов, М.Е. Резван (ред.) Лавровский сборник: Материалы ХХХVІ и ХХХVII Среднеазиатско-Кавказских чтений 2012-2013 гг.: этнология, история, археология, культурология. СПб.: МАЭ РАН:372-375.

Нагиева М.К. (ред.) (2015) История развития здравоохранения в Дагестане в ХХ в. T. I (1900 - июнь 1941 гг.). Документы и материалы. Махачкала: ИИАЭ ДНЦ РАН.

Омаров А.С. (ред.) (1968) Из истории права народов Дагестана. (Материаль и документы). Махачкала: ИИЯЛ ДФ АН СССР.

Пыпа А.И. (1960) Развитие здравоохранения в Лакском районе за 40 лет (1920-1960 гг.). Научная конференщия, посвященная 40-летию со дня установления Советской власти в Дагестане. (Тезисы и авторефераты докладов). Махачкала: ДМИ: 131-133.

Саградов [И.Н.] (1920) Здравоохранение в Дагестане. (Из доклада народному комиссару здравоохранения). Советский Дагестан, (28): 2 .

Смирнова Я.С. (1983) Семья и семейный быт народов Северного Кавказа. Вторая половина $X I X-X X$ вв. М.: Наука.

Яхъяева З.И. (2014) Основные направления развития акушерско-гинекологической помощи на Северном Кавказе в XIX-XX вв.: автореф. дисс... докт. мед. наук. Москва: [б.и.].

Яхъяева 3.И., Батаев Х. М. (2012) Развитие профилактического направления в охране материнства и младенчества в республиках Северного Кавказа в первой половине XX века. Вопросы современной педиатрии, (1): 10-13.

Djandar M. (2008) Rituals of Birth among the Adyghes. Iran \& the Caucasus, (2):253-274.

Hoffmann D. L. (2011) Cultivating the Masses: Modern State Practices and Soviet Socialism, 1914-1939. Ithaca: Cornell University Press. 
Sergey Manyshev

\section{MOTHER AND CHILD IN EARLY SOVIET SOCIAL POLICY: THE CASE OF DAGESTAN}

The paper analyzes the Soviet social policy of 1920-1930 in the field of maternity and childhood protection in Dagestan. Based on archival materials introduced for the first time, as well as an analysis of published documents, literature and periodical press materials, I reveal the main trends of early Soviet policy. This analysis made it possible to build a holistic picture of the transformations in the field of medical care for women, their emancipation, and inclusion in public life. These documentary materials reflect the difficulties the Soviet authorities faced in their attempts to penetrate and transform Dagestan's villages. One key example was how Soviet health care collided with traditional medical practices in Dagestan. The traditional healers formed the basis of medical care with most using the services of local midwives who had no professional education. This was due to the lack of specialized educational institutions in the region. However, in the mid-1920s, an obstetric-paramedic school was opened, which began to train qualified medical workers. As statistics show, before the ban on abortions was introduced, their number in Dagestan was significant. The ban imposed on abortion led to a growth of fertility, which in turn led to the opening of the maternity hospital in the capital of the republic. The opening of the Dagestan Medical Institute in 1932 and the creation of the departments of children's diseases and obstetrics and gynecology had a positive impact on the provision of skilled medical care to mothers and children. The article shows that despite the famine, the reluctance of local residents to resort to qualified medical care, as well as other difficulties associated with the conduct of Soviet social policy, a considerable increase in population was observed in Dagestan in the 1920s-1930s.

Keywords: Dagestan, maternity protection, health history, social policy, obstetrics

DOI: $10.17323 / 727-0634-2019-17-1-75-88$

\section{References}

Abdulzhanova F. S. (1978) Ohrana zdorov' ja zhenshhiny-materi i rebenka [Protecting the Health of Mother and Child]. Mahachkala: Dagknigoizdat.

Aliev M. (1937) Makhachkale nuzhen rodil'nyy dom [Makhachkala Needs a Maternity Hospital]. Dagestanskaya Pravda [Dagestan Truth], (51): 3 .

Alikishiev R. Sh. (1958) Ocherki po istorii zdravookhraneniya Dagestana [Essays on the History of Public Health in Dagestan]. Moscow: Medgiz.

Andreev E. M., Darskiy L. E., Khar'kova T. L. (1993) Naselenie Sovetskogo Soyuza. 1922-1991 [The Population of the Soviet Union. 1922-1991]. Moscow: Nauka.

Ayvazova S. (1899) Narodnoe akusherstvo v Zakatal'skom okruge. (Iz zapisok akusherki) [Folk Obstetrics in the Zakatala District. (From Midwife Notes)]. Akusherka: Obshchedostupnyy meditsinskiy zhurnal [Midwife: Public Medical Journal], (13-14):203-210.

Sergey B. Manyshev - PhD candidate, The Institute of Russian History of the Russian Academy of Sciences, Moscow, Russian Federation. Email: msergey1990@gmail.com 
Bobrovnikov V.O. (ed.) (2009) Obychay i zakon v pis'mennykh pamyatnikakh Dagestana Vnachala XX v. T. II: V tsarskoy i ranney sovetskoy Rossii [Custom and Law in Written Monuments of Dagestan V - Early XX Century. Vol. II: In Tsarist And Early Soviet Russia]. Moscow: Mardzhani.

Dagestanskaya Pravda (1936) Znakharskoe 'akusherstvo' [The 'Obstetrics' of Healers], (137): 2. Dagestanskaya Pravda (1939) Mezhrespublikanskaya konferentsiya po bor'be s detskimi zabolevaniyami [Interrepublican Conference on Combating Childhood Illnesses], (70): 4.

Djandar M. (2008) Rituals of Birth among the Adyghes. Iran \& the Caucasus, (2):253-274.

Dzagurova Yu.P., Mikhaylova N.V. (eds.) (1979). Velikiy Oktyabr' i raskreposhchenie zhenshchin Severnogo Kavkaza i Zakavkaz'ya. 1917-1936 gg. Sbornik dokumentov i materialov [Great October and the Emancipation of Women in the North Caucasus and Transcaucasia. 1917-1936. Collection of Documents and Materials]. Moscow: Mysl'.

Epifanova A. G. (1930) Plodovitost' darginskoy zhenshchiny i detskaya smertnost' [Fertility of the Dargin Woman and Infant Mortality]. In: A. V. Mol'kov (ed.) Sotsial'no-gigienicheskoe issledovanie narodnostey Dagestana. Vyp. I: Dargintsy [Socio-Hygienic Study of the Nationalities of Dagestan. Iss. I: The Dargins]. Moscow; Leningrad: Medgiz: 61-75.

Gindoman D. (ed.) (1939) Sbornik polozheniy i instruktsiy po rabote uchrezhdeniy rodovspomozheniya [Collection of Regulations and Instructions on the Work of Institutions of Obstetrics]. Moscow: [n.d.].

Hoffmann D. L. (2011) Cultivating the Masses: Modern State Practices and Soviet Socialism, 1914-1939. Ithaca: Cornell University Press.

Ibragimov M.-R.A. (2013) Demograficheskaya situatsiya v Dagestane v gody Grazhdanskoy voyny [The Demographic Situation in Dagestan During the Civil War]. In: B. B. Bulatov (ed.) Severo-kavkazskiy istoricheskiy diskurs Grazhdanskoy voyny v Rossii (1917-1922 gg.). Materialy mezhdunarodnoy nauchno-prakticheskoy konferentsii, posvyashchennoy 200-letiyu vkhozhdeniya Dagestana v sostav Rossii, 20 oktyabrya 2013 g. Vyp. 1 [The North-Caucasian Historical Discourse on the Civil War in Russia (1917-1922). Materials of the International Scientific and Practical Conference Dedicated to the $200^{\text {th }}$ Anniversary of Dagestan's Entry into Russia, October 20, 2013. Iss. 1]. Makhachkala: DGU: 74-80.

Imamaliev [S.] (1927) Znakharstvo v Dagestane [Witchcraft in Dagestan]. Krasnyy Dagestan [Red Dagestan], (37): 2 .

Israpilov A.K.-M. (ed.) (1960) Revolyutsionnye komitety Dagestana i ikh deyatel'nost' po uprocheniyu Sovetskoy vlasti i organizatsii sotsialisticheskogo stroitel'stva. (Mart 1920 g.-dek$a b r$ ' 1921 g.) [The Revolutionary Committees of Dagestan and Their Activities to Consolidate Soviet Power and Organize Socialist Construction]. (March 1920 - December 1921)]. Makhachkala: Dagestanskoe knizhnoe izdatel'stvo.

Kazarov [S.] (1938a) Vnimanie detskoy ambulatorii [Attention to the Children's Dispensary]. Dagestanskaya Pravda [Dagestan Truth], (22): 3 .

Kazarov [S.] (1938b) Sozvat' konferentsiyu vrachey-pediatrov [The Need to Convene a Conference of Pediatricians]. Dagestanskaya Pravda [Dagestan Pravda], (293): 3.

Kizileva M. (1938) Rasskaz sel'skoy akusherki [The Story of a Rural Midwife]. Dagestanskaya Pravda [Dagestan Pravda], (300): 3.

Kogan G. D., Yusupova S.I. (eds.) (1980) Kul'turnoe stroitel'stvo v Dagestanskoy ASSR. T. 1: 19181941. Sbornik dokumentov [Cultural Construction in the Dagestan ASSR. T. 1: 1918-1941. Collection Of Documents]. Makhachkala: Dagestanskoe knizhnoe izdatel'stvo.

M. M. (1930) Pokazateli rannej detskoj smertnosti v gorodah DASSR v svjazi s pokazateljami rozhdaemosti i obshhej smertnosti [Indicators of Early Infant Mortality in the Cities Of Daghes$\tan$ in Connection With Fertility and Total Mortality]. Planovoe hozjajstvo Dagestana [Planned Economy of Dagestan], (1-2): 97-102.

Magomedov A.D. (1980) Dvizhenie naseleniya Dagestana v gody Grazhdanskoy voyny [Movement of the Population of Dagestan During the Civil War.]. In: G. Kaymarazov (ed.) Grazhdanskaya voyna na Severnom Kavkaze. (Zakonomernosti i osobennosti): Regional'naya nauchnaya konferentsiya. Tezisy dokladov [Civil War in the North Caucasus. (Regularities and Features): Regional Scientific Conference. Theses of Reports]. Makhachkala: IIYaL DF AN SSSR:42-43.

Malygin M. (1927) K voprosy o estestvennom dvizhenii naseleniya DSSR. (Opyt issledovaniya) [On the Issue of the Natural Movement of the Population of the DSSR. (Research Experience).]. Planovoe khozyaystvo Dagestana [Planned Economy of Dagestan], (7-8): 81-118. 
Markin A. I. (1927) Lechebnoe delo v avtonomnykh oblastyakh Severo-Kavkazskogo kraya [Healing in the Autonomous Regions of the North Caucasus]. Sovetskaya meditsina na Severnom Kavkaze [Soviet Medicine in the North Caucasus], (10):3-10 .

Monin L.M. (1905) O nravakh i obychayakh sredi musul'manskogo naseleniya nekotorykh mestnostey Zakavkaz'ya i Severnogo Kavkaza po otnosheniyu k beremennym, rozhenitsam, rodil'nitsam i novorozhdennym [On the Customs and Customs Among the Muslim Population of Certain Areas of Transcaucasia and the North Caucasus in Relation to Pregnant Women, Parturient Women, Mothers and Newborns]. Meditsinskiy sbornik, izdavaemyy imperatorskim Kavkazskim meditsinskim obshchestvom [The Medical Collection Published by the Imperial Caucasian Medical Society]. SanktPeterburg: Tipografiya T-va M.O. Vol'fa: 67:99-114.

Musaeva M.K. (2013) Vnutrisemeynyy kontrol' rozhdaemosti: traditsionnaya praktika primeneniya kontratseptsii u narodov Dagestana [Intrafamily Birth Control: Traditional Practice of Contraceptive Use Among the Peoples of Dagestan]. In: Yu.Yu. Karpov, M.E. Rezvan (eds.) Lavrovskiy sbornik: Materialy XXXVI i XXXVII Sredneaziatsko-Kavkazskikh chteniy 2012-2013 gg.: etnologiya, istoriya, arkheologiya, kul'turologiya [Lavrovsky Collection: Materials XXXVI and XXXVII Central Asian-Caucasian Readings 2012-2013: Ethnology, History, Archeology, Culturology]. Sankt-Peterburg: MAE RAN:372-375.

Nagieva M.K. (comp.) (2015) Istoriya razvitiya zdravookhraneniya v Dagestane $v$ XX v. T. I (1900 - iyun' 1941 gg.). Dokumenty i materialy [A History of Health Development in Dagestan in the 20th Century. Vol. I (1900 - June 1941). Documents and Materials]. Makhachkala: IIAE DNTs RAN.

Omarov A. S. (comp.) (1968) Iz istorii prava narodov Dagestana. (Materialy i dokumenty) [From the History of the Law of the Peoples of Dagestan. (Materials and Documents)]. Makhachkala: IIYaL DF AN SSSR.

Pypa A.I. (1960) Razvitie zdravoohranenija v Lakskom rajone za 40 let (1920-1960 gg.) [Development of Health Care in the Lak District for 40 Years (1920-1960)]. Nauchnaja konferencija, posvjashhennaja 40-letiju so dnja ustanovlenija Sovetskoj vlasti v Dagestane. (Tezisy i avtoreferaty dokladov) [Scientific Conference Dedicated to the $40^{\text {th }}$ Anniversary of the Establishment of Soviet Power in Dagestan. (Abstracts and Abstracts of Papers)]. Mahachkala: DMI: 131-133.

Sagradov [I.N.] (1920) Zdravookhranenie v Dagestane. (Iz doklada narodnomu komissaru zdravookhraneniya) [Healthcare in Dagestan. (From the Report to the People's Commissar of Health)]. Sovetskiy Dagestan [Soviet Dagestan], (28): 2 .

Smirnova Ya.S. (1983) Sem'ya i semeynyy byt narodov Severnogo Kavkaza. Vtoraya polovina $X I X-X X v v$. [Family and Family Life of the Peoples of the North Caucasus. The Second Half of the XIX-XX Centuries]. Moscow: Nauka.

Vishnevskij A. G. (ed.) (2006) Demograficheskaja modernizacija Rossii, 1900-2000 [The Demographic Modernization of Russia, 1900-2000]. Moscow: Novoe izdatel'stvo.

Yakh"yaeva Z.I. (2014) Osnovnye napravleniya razvitiya akushersko-ginekologicheskoy pomoshchi na Severnom Kavkaze v XIX-XX vv.: avtoref. diss... dokt. med. nauk [The Main Directions of Development of Obstetric and Gynecological Care in the North Caucasus in the XIX-XX Centuries: Dissertation Theses]. Moscow: [b.i.].

Yakh"yaeva Z.I., Bataev Kh.M. (2012) Razvitie profilakticheskogo napravleniya v okhrane materinstva i mladenchestva v respublikakh Severnogo Kavkaza v pervoy polovine XX veka [Development of the Preventive Direction in the Protection of Motherhood and Infancy in the Republics of the North Caucasus in the First Half of the $20^{\text {th }}$ Century]. Voprosy sovremennoy pediatrii [Questions of Modern Pediatrics], (1): 10-13.

Zavalishchenko L.I. (comp.) (1973) Zdravookhranenie v gody vosstanovleniya i sotsialisticheskoy rekonstruktsii narodnogo khozyaystva SSSR. 1925-1940. Sbornik dokumentov i materialov [Public Health in the Years of Reconstruction and Socialist Reconstruction of the National Economy of the USSR. 1925-1940. Collection of Documents and Materials]. Moscow: Meditsina.

Zhiromskaya V.B. (ed.) (2000) Naselenie Rossii v XX veke: Istoricheskie ocherki. T. 1: 1900-1939 [Population of Russia in the $20^{\text {th }}$ Century: Historical Essays. T. 1: 1900-1939]. M.: ROSSPEN.

Zhiromskaya V.B., Polyakov Yu.A. (eds.) (2007) Vsesoyuznaya perepis' naseleniya 1937 goda: Obshchie itogi: Sbornik dokumentov i materialov [All-Union Population Census of 1937: General Results: Collection of Documents and Materials]. Moscow: ROSSPEN. 